\title{
Proteomic analysis of Clostridium acetobutylicum in butanol production from lignocellulosic biomass
}

\author{
Kumaran Sivagnanam ${ }^{1 *}$, Vijaya G S Raghavan ${ }^{1}$, Manesh Shah², Nathan C Verberkmoes ${ }^{2}$, Robert L Hettich², \\ Mark G Lefsrud ${ }^{1}$ \\ From IUFRO Tree Biotechnology Conference 2011: From Genomes to Integration and Delivery \\ Arraial d'Ajuda, Bahia, Brazil. 26 June - 2 July 2011
}

\section{Background}

Plant biomass is an abundant and renewable source of energy rich carbohydrates that can be efficiently converted by microbes into biofuels [1]. Butanol is considered as a second generation biofuel when it is produced from lignocellulosic biomass comprising of agricultural and garden wastes that does not compete with the food supplies [2]. Clostridium acetobutylicum is a gram positive, spore forming, obligately anaerobic bacteria capable of converting different sugars from lignocellulosic biomass to butanol through acetone - butanol - ethanol (ABE) fermentation process [3]. However, the production of butanol from ABE fermentation process is not economically viable and studies have been performed to understand the utilization of lignocellulosic biomass and regulation of butanol production to improve butanol productivity [4]. Successful industrial butanol production process through $\mathrm{ABE}$ fermentation requires complete understanding of the $C$.acetobutylicum. Shotgun proteomics provides a direct approach to study the whole proteome of an organism at molecular level in depth. Therefore, this paper focuses on shotgun proteomic profiling of C. acetobutylicum ATCC 824 from butanol fermentation process, elucidating the molecular functional mechanisms of C.acetobutylicum in butanol production.

\section{Materials and methods}

The microorganism C.acetobutylicum bacterial strain ATCC-824 was cultured [5] and ABE fermentations were carried out in batch mode using glucose substrate which

\footnotetext{
* Correspondence: kumaran.sivagnanam@mail.mcgill.ca

${ }^{1}$ McGill University, USA

Full list of author information is available at the end of the article
}

is the most abundant compound present in lignocellulosic biomass. Samples of $10 \mathrm{ml}$ were harvested at late exponential phase from the start of the inoculation and proteins were extracted followed by digestion to peptides. The complex peptide solution was desalted through C18solid-phase extraction, concentrated, filtered and for each LC-MS/MS analysis, $\sim 1 / 4$ of the total sample was used based on the protocol used by [6]. Samples were analyzed in technical duplicates through a 2D nano-LC MS/MS system with a split-phase column (RPSCX-RP) with 12hr runs [7-9]. All MS/MS spectra were searched with the SEQUEST algorithm [10]against $C$. acetobutylicum Uniprot proteome databases [11] and filtered with DTASelect/Contrast [9] at the peptide level. Only proteins identified with two fully tryptic peptides from a $12 \mathrm{hr}$ run were considered for further biological study.

\section{Results}

A total of 479 proteins were identified in the proteome analysis of $C$. acetobutylicum from a single data point during the $\mathrm{ABE}$ fermentation process and 372 proteins were found to be present in both the first and second MS runs and identified as common proteins. This analysis confirms that 12 proteins were involved in the butanoate metabolism and about 32 uncharacterized proteins were found to be present during the ABE fermentation using glucose substrate. Overall, this is the first study which represents an extensive survey of whole proteome analysis of C.acetobutylicum from a single data point by multidimensional protein identification technology (MudPIT) and provides a valuable dataset of C.acetobutylicum proteins for a better understanding of the butanol production. 


\section{Author details}

${ }^{1}$ McGill University, USA. ${ }^{2}$ Oak Ridge National Laboratory, USA.

Published: 13 September 2011

\section{References}

1. Antoni D, Zverlov W, Schwarz WH: Biofuels from microbes. Applied Microbiology and Biotechnology 2007, 77(1):23-35.

2. Festel GW: Biofuels - Economic aspects. Chemical Engineering \& Technology 2008, 31(5):715-720.

3. Husemann MHW, Papoutsakis ET: Enzymes Limiting Butanol and Acetone Formation in Continuous and Batch Cultures of ClostridiumAcetobutylicum. Applied Microbiology and Biotechnology 1989, 31(56):435-444.

4. Ezeji TC, Qureshi N, Blaschek HP: Bioproduction of butanol from biomass: from genes to bioreactors. Current Opinion in Biotechnology 2007, 18(3):220-227.

5. Harris LM, Welker NE, Papoutsakis ET: Northern, morphological, and fermentation analysis of spo0A inactivation and overexpression in Clostridium acetobutylicum ATCC 824. Journal of Bacteriology 2002, 184(13):3586-3597.

6. Verberkmoes NC, Russell AL, Shah M, Godzik A, Rosenquist M, Halfvarson J, Lefsrud MG, Apajalahti J, Tysk C, Hettich RL, et al: Shotgun metaproteomics of the human distal gut microbiota. Isme Journal 2009, 3(2):179-189.

7. Lo I, Denef VJ, VerBerkmoes NC, Shah MB, Goltsman D, DiBartolo G, Tyson GW, Allen EE, Ram RJ, Detter JC, et al: Strain-resolved community proteomics reveals recombining genomes of acidophilic bacteria. Nature 2007, 446(7135):537-541.

8. Ram RJ, VerBerkmoes NC, Thelen MP, Tyson GW, Baker BJ, Blake RC, Shah M, Hettich RL, Banfield JF: Community proteomics of a natural microbial biofilm. Science 2005, 308(5730):1915-1920.

9. Tabb DL, McDonald WH, Yates JR: DTASelect and contrast: Tools for assembling and comparing protein identifications from shotgun proteomics. Journal of Proteome Research 2002, 1(1):21-26.

10. Eng JK, Mccormack AL, Yates JR: An Approach to Correlate Tandem MassSpectral Data of Peptides with Amino-Acid-Sequences in a Protein Database. Journal of the American Society for Mass Spectrometry 1994 5(11):976-989.

11. Apweiler R, Bairoch A, Wu CH, Barker WC, Boeckmann B, Ferro S, Gasteiger E, Huang HZ, Lopez R, Magrane M, et al: UniProt: the Universal Protein knowledgebase. Nucleic Acids Research 2004, 32:D115.

doi:10.1186/1753-6561-5-S7-P176

Cite this article as: Sivagnanam et al:: Proteomic analysis of Clostridium acetobutylicum in butanol production from lignocellulosic biomass. BMC Proceedings 2011 5(Suppl 7):P176.

\section{Submit your next manuscript to BioMed Central and take full advantage of:}

- Convenient online submission

- Thorough peer review

- No space constraints or color figure charges

- Immediate publication on acceptance

- Inclusion in PubMed, CAS, Scopus and Google Scholar

- Research which is freely available for redistribution

Submit your manuscript at www.biomedcentral.com/submit
Biomed Central 